\title{
Energy Partitioning by Litopenaeus vannamei (Boone, 1931) Given Plant Protein Diets
}

\author{
Suárez JA ${ }^{1 *}$, Gaxiola $\mathbf{G}^{3}$, Posso $\mathbf{R}^{2}$, Garcia $\mathbf{G}^{5}$, Alanis $\mathbf{G}^{5}$, Suárez A $^{2}$, Faillace $\mathrm{J}^{2}$ and Cuzon $\mathbf{G}^{4}$ \\ 1 UNIVERSITY OF MIAMI, Rosenstiel School of Marine \& Atmospheric Science, Miami, USA. \\ ${ }^{2}$ CENIACUA, Corporación Centro Investigación de la Acuicultura de Colombia, Punta Canoa, Cartagena de Indias, Colombia \\ UNAM, Unidad Multidisciplinaría de Docencia e Investigación, Facultad de Ciencias, Sisal, Yucatán Lab Ecophysiologia, Sisal, Yucatan, Mexico. \\ ${ }^{4}$ Ifremer/COP, BP 7004 Taravao, Tahiti, French Polynesia \\ ${ }^{5}$ Universidad Autónoma de Nuevo León, Facultad de Ciencias Biológicas, San Nicolás de los Garza, Nuevo Léon, México
}

\begin{abstract}
The nutritive value of soybean meal (SBMd), feed pea meal (FPMd) and canola meal (CNAd) was evaluated for the shrimp $L$. vannamei. The apparent digestive coefficient (ADC) of dry matter (DM) varied from $80-86 \%$ for diets $(p<0.05)$ and $64-87 \%$ for ingredients $(p<0.05)$. ADC protein varied in a narrow range but still differed amongst diets $(p<0.05)$; CNA provided the least ADC protein. ADC energy followed the same pattern as ADC protein but the range of variation was higher (87-92\%) than with protein. All parameters derived from oxygen consumption were measured to determine an energy budget calculated on a $24 \mathrm{~h}$ basis, with animals weighing $6 \mathrm{~g}$ on average and given practical diets. SBMd and FPMd yielded recovered energy (RE) of 0.9 and $0.7 \mathrm{~kJ}$, respectively, in comparison to CNAd, which yielded a value as low as $0.4 \mathrm{~kJ}$ RE. The latter thus represents a poor diet alternative as compared to soy or pea meal diets in terms of energy use for growth. Substrates were provided to shrimp at a high level and trypsin was able to hydrolyze all protein sources similarly. The result of this process was protein with tertiary structures. Such structures could be attacked in peptide chain regions where radical $-\mathrm{COOH}$ is present and at Arg and Lys linkages. A priori, the results of hydrolysis would release the same amount of amino acid. Therefore, any difference in ADC will be derived from the presence of inhibitor or from excess nitrogen-free extract. This could explain the lower ADC protein value observed with CNA. Diets fed to shrimp led to an energy budget where a large part of the energy was derived from catabolism of amino acids. Such budgets typically reflect a better output from SBM and FPM as compared to CAN. Therefore, we conclude that ADC is a useful tool for evaluating vegetable-derived protein in the formulation of shrimp diets.
\end{abstract}

Keywords: L. vannamei; Plant proteins; Digestibility; Metabolism

\section{Introduction}

World aquaculture shrimp production in 2004 was $6.1 \mathrm{mt}$ [1], of which $2.5 \mathrm{mt}$ (41\%) was obtained through shrimp farming. Farmed shrimp are generally fed manufactured feeds that contain approximately $25 \%$ fish meal. Protein ingredients selected to substitute fish meals, either partially or completely, include terrestrial plant and animal byproducts that are readily available on world markets [2]. The quantity and quality of dietary protein are primary factors influencing shrimp growth, nitrogen loading of the culture system and feed costs. Considerable research has been conducted to evaluate the suitability of various vegetable-derived feed ingredients as alternative protein sources for fish meal [3]. Plant-based ingredients are tested with increasing frequency in formulated feeds for shrimp. Research has revealed the presence of anti-nutritional factors in soy bean meal (SBM), although these factors may be eliminated through heat treatment (extrusion), a process that also improves the digestibility of soybean protein [5]. Some studies have focused on the use of soybean meal for shrimp [6-8]. However, other plant sources such as peas, Pisum sativum $[9,10]$, and canola low in glucosinolate and erucid acid [11-13] are also available and regarded as potential sources of protein for shrimp diets.

Measuring the apparent digestive coefficient (ADC) of nutrients in an ingredient or a feed provides a very practical estimate, though sometimes overestimated, of nutrient availability [14,15]. An advantage of this method over testing single ingredients is that test ingredients could be more acceptable to animals when supplied in combination with other ingredients and may lead to a normal level of feed intake [16]. Nutrient digestibility can be measured far more readily than nutrient availability. This parameter is widely reported in discussions [17] of the options for alternative compounded feeds. The digestibility of ingredients and diets has been described by many authors [3,16,18-21] and differences between diets may be explained by the amount of indigestible energy, poorly digestible ingredients in the formulation $[2,3]$ and/or leaching $[14,15]$. Leaching prior to feces collection was observed with P. setiferus [19] and led to occasional overestimation of digestibility. Careful monitoring of the residence time of fecal material in water and collection of the feces within $30 \mathrm{~m}$ after ingestion limited the problem. Furthermore, the peritrophic membrane of the fecal strands is likely to prevent strand collapse and reduced nutrient loss, to some extent [22]. Loss of soluble nutrients from feces was described in fish by De la Noüe et al. [23]. Given the difficulties of undertaking field studies, it was found that an in vitro method allowed the collection of information on nutrient digestibility and the determination of the ADC of ingredients [21]. Results of a study undertaken by Forster [20] with L. vannamei yielded low statistical variability that confirmed the in vitro model as being acceptable for shrimp. There is also need to evaluate feed utilization by shrimp to predict waste outputs for different species; the use of a bioenergetics approach has been demonstrated to be effective in fish [24,25]. In contrast, crustacean species, in particular penaeid shrimp, provide only

*Corresponding author: Suarez JA, University of Miami, Rosenstiel School of Marine \& Atmospheric Science, Miami, Florida, USA ,Tel: (1)305-968-5849; Fax: (305) 421-4675; E-mail: jsuarez@rsmas.miami.edu

Received January 12, 2012; Accepted March 01, 2012; Published March 28, 2012

Citation: Suárez JA, Gaxiola G, Posso R, Garcia G, Alanis G, et al. (2012) Energy Partitioning by Litopenaeus Vannamei (Boone, 1931) given Plant Protein Diets. J Aquac Res Development 3:128 doi:10.4172/2155-9546.1000128

Copyright: () 2012 Suárez JA, et al. This is an open-access article distributed under the terms of the Creative Commons Attribution License, which permits unrestricted use, distribution, and reproduction in any medium, provided the original author and source are credited. 
limited information [26,27]. In this study on L. vannamei juveniles, we evaluated the nutritive value of soy bean meal (SBM), feed pea meal $(\mathrm{FPM})$ and canola (CNA) as candidate ingredients in practical diets. Energy partitioning by shrimp fed these protein sources was studied to develop feeds with minimal fishmeal content and waste products.

\section{Materials and Methods}

At a local research facility, all shrimp were received from CENIACUA and derived from a process of selection reaching the $\mathrm{F}^{10}$ generation. We studied domesticated animals adapted to their environment and fed with commercial feed including $40 \% \llbracket \mathbb{C P}$ and $\sim 23 \%$ carbohydrates.

The experimental tanks had the following dimensions: diameter, $1.5 \mathrm{~m}$; height, $0.5 \mathrm{~m}$; volume, $883 \mathrm{~L}$. Effects of dietary treatments were analyzed with regard to feed intake, ADC dry matter, energy and protein.

\section{Diets and ingredients}

The diets were formulated on an as-fed basis and are presented in Table 1 . The diets were prepared by mixing dry ingredients for $10 \mathrm{~min}$ in a bowl, then liquid ingredients were poured and mixed for an additional $10 \mathrm{~min}$. Mixed ingredients were then steam-pelleted at $90\left[2^{\circ} \mathrm{C}\right.$ through a $2.5 \times 3 \mathrm{~mm}$ die. Pellets were oven-dried at $73^{\circ} \mathrm{C}$ under constant air for $45 \mathrm{~min}$, bagged, and stored in a cool room at $24^{\circ} \mathrm{C}$. Two percent Celite ${ }^{\circ} \mathrm{NF}$ (acid-washed standard Super-Cel ${ }^{\circ} \mathrm{NF}$, Celite Corporation, Lompoc, CA, USA) was included in the experimental diets as an inert indicator. Chemical contents of the experimental diets were obtained and are given in Table 2.

\section{Analytical procedure}

Chemical analyses were carried out on ingredients, diets and juvenile shrimp carcasses. Protein levels were calculated from the determi-

\begin{tabular}{|c|c|c|c|c|}
\hline & ref.diet & SBMd & FPMd & CNAd \\
\hline fish meal $^{\mathrm{a}}$ & 33 & 23.1 & 23.1 & 23.1 \\
\hline squid meal & 3.0 & 2.1 & 2.1 & 2.1 \\
\hline soybean meal & & 30 & & \\
\hline pea feed meale & & & 30 & \\
\hline canola meal $^{f}$ & & & & 30 \\
\hline soybean meal & 17 & 11.9 & 11.9 & 11.9 \\
\hline wheat gluten $^{b}$ & 12 & 8.4 & 8.4 & 8.4 \\
\hline wheat flour & 26.2 & 17.7 & 17.7 & 17.7 \\
\hline fish oil & 4 & 2.8 & 2.8 & 2.8 \\
\hline soybean lecithin & 2 & 1.4 & 1.4 & 1.4 \\
\hline cholesterol & 0.5 & 0.35 & 0.35 & 0.35 \\
\hline vit. \& min. premix ${ }^{c}$ & 0.25 & 0.25 & 0.25 & 0.25 \\
\hline celite $^{d}$ & 2 & 2 & 2 & 2 \\
\hline
\end{tabular}

a Peruvian fishmeal; ${ }^{\text {b }}$ Vital wheat gluten (Flour \& Starch Union); Defatted soybean meal and solvent-extracted regular SBM, properly cooked and used in poultry feeds. Pea meal flour produced with selected varieties of yellow peas picked up in France from Sopropeche; the flour was obtained using a physical process combining de-hulling, micro-grinding and extrusion with low amounts of residual anti-trypsin factor $(<600 \mathrm{UI})$. Canola meal purchased from Canada. ${ }^{\circ}$ Vitamin and mineral premix includes (IU/kg or g/kg or $\mathrm{mg} / \mathrm{kg}$ of premix): Vit. A, $10000 \mathrm{IU} / \mathrm{g}$; $B_{1}, 30 \mathrm{mg} / \mathrm{kg} ; B_{2}, 15 \mathrm{mg} / \mathrm{kg}$; DL Ca pantothenate, $50 \mathrm{mg} / \mathrm{kg} ; B_{6}, 35 \mathrm{mg} / \mathrm{kg} ; B_{12}$ $40 \mathrm{mcg} / \mathrm{kg}$; Ascorbic, $150 \mathrm{mg} / \mathrm{kg} ; \mathrm{K}_{3}, 3 \mathrm{mg} / \mathrm{kg} ; \mathrm{D}_{3}, 3500 \mathrm{IU} / \mathrm{g} ; \mathrm{E}, 150 \mathrm{IU} / \mathrm{g}$; niacin $100 \mathrm{mg} / \mathrm{kg}$; folic acid, $4 \mathrm{mg} / \mathrm{kg}$; biotin, $1000 \mathrm{mcg} / \mathrm{kg} ; \mathrm{Mn}, 40 \mathrm{mg} / \mathrm{kg} ; \mathrm{Zn}, 40 \mathrm{mg} / \mathrm{kg}$; $\mathrm{Cu}, 25 \mathrm{mg} / \mathrm{kg}$; Fe, $100 \mathrm{mg} / \mathrm{kg}$; Se, $0.3 \mathrm{mg} / \mathrm{kg} ; \mathrm{l}, 0.35 \mathrm{mg} / \mathrm{kg}$. d Celite. Acid-washed standard super-cel ${ }^{\circledR N F}$. Celite corporation, Lompoc, CA, USA. e Pea feed meal (Sopropeche, Boulogne-Sur-Mer, Cedex, France) fCanola meal (Bunge Canada, Altona Manitoba, Canada).

Table 1: Diet composition (\% as fed) of reference and tests SBMd, FPMd and CNAd.

\begin{tabular}{|l|l|l|l|l|}
\hline & ref.d. & SBMd & FPMd & CNAd \\
\hline protein (Nx6.25) & 43 & 45 & 39 & 44 \\
\hline LYS & 2.7 & 2.7 & 2.7 & 2.9 \\
\hline ARG & 2.1 & 2.2 & 2.3 & 2.3 \\
\hline HIS & 1.0 & 1.0 & 1.0 & 1.1 \\
\hline LEU & 2.9 & 3.0 & 2.9 & 3.1 \\
\hline ILE & 1.8 & 1.9 & 1.8 & 1.9 \\
\hline VAL & 2.1 & 2.2 & 2.2 & 2.3 \\
\hline THR & 1.5 & 1.6 & 1.6 & 1.7 \\
\hline MET & 1.0 & 1.0 & 0.9 & 1.1 \\
\hline PHE & 1.6 & 1.7 & 1.7 & 1.7 \\
\hline TRP & 0.5 & 0.6 & 0.4 & 0.5 \\
\hline crude fat & 10 & 8 & 7 & 9 \\
\hline carbohydrate & 25 & 29 & 38 & 26 \\
\hline DE $(k J / g$ DM) & 18 & 19 & 18 & 16 \\
\hline crude fiber & 3 & 1 & 1 & 3 \\
\hline moisture & 8.4 & 7.5 & 6.8 & 7.8 \\
\hline ash & 9 & 9 & 8 & 9 \\
\hline \% DM loss & $10^{\mathrm{a}}$ & $12^{\mathrm{c}}$ & $10^{\mathrm{a}}$ & $12^{\mathrm{b}}$ \\
\hline
\end{tabular}

a carbohydrate (by difference).

${ }^{\mathrm{b}}$ stability of the diets in dry matter (DM) after $1 \mathrm{~h}$-immersion in seawater (Aquacop 1978). Values were means of four replicates. Means within columns with the same letter were not significantly different at $p<0.05$

${ }^{c}$ Reference diet abbreviated as ref. $d$

Table 2: Analytical composition of experimental diets (\% as fed).

nation of total nitrogen with a LECO auto-analyzer, and the calculation was based on $\mathrm{N} x 6.25$ (A.O.C.S, No. Aa 5-91). Dietary crude fat content was determined gravimetrically following lipid extraction using the Soxhlet method (A.O.A.C, No. 920.39), and amino acid determination was performed with an automatic AA analyzer ([4,28], No.988.15). Feed and animal energy content were measured using an adiabatic bomb calorimeter. The procedures for analyzing moisture (A.O.A.C., No. 934.01), crude fiber (A.O.A.C, No. 962.09) and ash (A.O.A.C, No. 942.05) were followed accordingly. Feed collets (obtained by cold extrusion) were tested for water stability, determined after $1 \mathrm{~h}$ in seawater [29].

\section{In vivo digestibility experiment}

The technique was previously described [22] and celite was the marker thoroughly mixed with other ingredients; practical feeds and feces were analyzed for marker using Acid-insoluble ash (AIA) content in diets and excreta was determined as in Atkinson et al. [30].

Water temperature was $26.7-30.4^{\circ} \mathrm{C}$, salinity was $34-36 \mathrm{gl}^{-1}$, and dissolved oxygen concentration was $6.0\left[\mathrm{f}\left[.8 \mathrm{mg} \mathrm{l}^{\mathrm{l}^{-1}}\right.\right.$. Each tank was stocked with 33 animals (11.4 $\square$ Q.9 g av. wt.). Treatments were randomly assigned to 16 tanks $(500 \mathrm{~L})$, with each treatment having four replicates. The shrimp were allowed to acclimatize to the dietary treatment for 10 days before fecal collection commenced. Shrimp were fed three times daily at 08:00, 12:00, and 21:00 h. Two hours after feeding, the rearing tanks were cleaned out to remove uneaten feed and fecal residues. Fecal matter was siphoned from each tank two times a day (10:00 and 14:00 h), and samples were gently rinsed with distilled water to eliminate excess salts. Daily fecal samples from each tank were pooled together before analysis.

ADCs in experimental diets were calculated according to the following formulae: 
The ratios in feces and feed based on respective marker concentrations provided an estimate for $\mathrm{ADC}_{\mathrm{DM}}$.

$\mathrm{ADC}_{\text {nutrient }}$ of diet $(\%)=100 \mathrm{x}[1-(\%$ marker in diet/ \% marker in feces) $] \mathrm{x}$ (nutrient concentration in feces/nutrient conc. in diet)] (2)

$\mathrm{ADC}_{\text {energy }}$ of diet $(\%)=100 \mathrm{x}[1-(\%$ marker in diet $/ \%$ marker in feces) $] \mathrm{x}$ (energy concentration in feces/energy conc. in diet)]

ADCs for ingredients were obtained with a combination of a reference diet and test diet; the composition of each is given in table 1. To calculate the ADC of ingredients, the following formula was used according to Forster [20]:



The reference diet substitution method has been applied for other species such as abalone and described by Sales \& Britz [16].

\section{Respirometry trial and energy budget}

Shrimp with $4.4 \pm 0.4 \mathrm{~g}$ average weight (av. wt) were allowed to acclimatize to the dietary treatment for 30 days prior to the beginning of the experiment. The technique described earlier [27] was applied to $L$. vannamei. Twelve shrimp per treatment were randomly taken $(5.8 \pm 0.4$ $\mathrm{g}$ av. wt.) for respirometry trials and energy budget calculations.

Water temperature was constant at $28^{\circ} \mathrm{C}$, salinity was $34-36 \mathrm{~g} \mathrm{l}^{-1}$ and dissolved oxygen concentration was $6.0 \pm 0.8 \mathrm{mg} \mathrm{l}^{-1}$. The information from the feeding trial was used to build an energy budget following the established nomenclature [31] and was based on energy partitioning, taking into account the following steps: intake (IE), digestible energy (DE), metabolizable energy (ME), urinary and branchial excretion $(\mathrm{UE}+\mathrm{ZE})$ and basal metabolism $(\mathrm{HeE})$. The feed administered and the remaining feed was determined in each metabolic chamber. The values of the digestible energy were obtained based on the daily consumption of feed/shrimp. Two chambers without animals were used as controls for each ten chambers stocked with shrimp. A metabolic chamber with continuous flow rate [32] allowed us to measure oxygen consumption individually for 12 shrimp $(5.8 \pm 0.4 \mathrm{~g})$ on each diet. Dissolved oxygen at the entrance and exit of respirometric chambers was measured using an oxygen micro-electrode (OXY 315i) and calculated according to: $\left.\mathrm{mn}^{-1}\right)$.

$\mathrm{O}_{2} \mathrm{mg} \mathrm{mn}^{-1}=\left[\mathrm{O}_{2} \operatorname{tank}\left(\mathrm{mg} \mathrm{L}^{-1}\right)-\mathrm{O}_{2} \text { control }\left(\mathrm{mg} \mathrm{L}^{-1}\right)\right]^{\star}$ flow rate $(\mathrm{L}$

Oxygen consumption transformed with the oxycalorific coefficient $13.6 \mathrm{~kJ} \mathrm{~g}^{-1} \mathrm{O}_{2}$ [24] yielded a value for heat production ( $\left.\mathrm{kJ}\right)$. Urinary and branchial excretion (UE+ZE) was calculated from the following equation: $\mathrm{UE}+\mathrm{ZE}=0.08^{\star}(\mathrm{RE}+\mathrm{HeE}+\mathrm{HiE}+\mathrm{HxE})$ from Bureau et al. [33], without taking into account the last item for molting $(\mathrm{HxE})$ due to the short duration of the study.

\section{Statistical methods}

All analyses were performed with the Statistical Analysis Software Program [34]. Apparent digestive coefficients were subjected to an analysis of variance, and Duncan's multiple range test provided the ranking.

\section{Results}

The reference diet was readily digested by juveniles. The fishmeal content was replaced by plant protein sources in the tested diets without significantly affecting the results; ADC for dry matter, protein and ener- gy of the diets examined is presented in Table 3. Diets differed with regard to dry matter, with the lowest value observed in CNAd (80\%). CNAd also showed the lowest $\mathrm{ADC}_{\text {protein }}(94 \%)$. Despite a narrow range of variation, $\mathrm{ADC}_{\text {protein }}$ differed amongst diets $(\mathrm{p}<0.05)$. $\mathrm{ADC}_{\text {energ }}$ followed the same pattern as $\mathrm{ADC}_{\text {protein }}$ but the range of variation (87-92\%) was higher than with protein.

$\mathrm{ADC}$ dry matter, protein and energy for the ingredients are presented in Table 4. The canola meal showed the lowest $\mathrm{ADC}_{\mathrm{DM}}(64 \%)$, $\mathrm{ADC}_{\text {protein }}(89 \%)$, and $\mathrm{ADC}_{\text {energy }}(75 \%)$ amongst all ingredients $(\mathrm{p}<0.05)$. There was no change between $\mathrm{SBM}$ and $\mathrm{FPM}$ in $\mathrm{ADC}_{\mathrm{DM}}, \mathrm{ADC}_{\text {protein }}$ and $\mathrm{ADC}_{\text {energy }}(\mathrm{p}>0.05)$. Final calculated values for $\mathrm{DE}$ were obtained with the coefficient previously determined by Cuzon \& Guillaume [35], and fitted with experimental data from the relevant test diet.

The amino acid profiles for the reference diet and the three test diets were similar (Table 2).

Animals ( $3-5 \mathrm{~g})$ fed experimental diets on a weekly basis were used to obtain the energy budget, the results of which are given in Table 5. SBMd and FPMd provided higher DE values (1.56 and $1.43 \mathrm{~kJ}^{\text {shrimp }}{ }^{-1}$ day $^{-1}$, respectively) than CNAd $\left(1.04 \mathrm{~kJ}\right.$ shrimp- 1 day $\left.^{-1}\right)$. Energy used for maintenance metabolism $(\mathrm{HeE})$ did not change at the dietary protein levels used for this experiment. The estimated value in $\mathrm{kJ}$ shrimp ${ }^{-1} \mathrm{day}^{-1}$ from UE+ZE for CNAd was only 0.06 while values for HiE (0.3) and $\mathrm{HeE}(0.25-0.32)$ were very similar for SBMd, FPMd and CNAd. Consequently, practical diets including canola meal did not provide sufficient energy ( $0.4 \mathrm{~kJ}$ shrimp-1day-1) for growth as compared to soya or feed pea and produced RE in the range of 0.7-0.9. RE was similar for both soy and pea meal diets, suggesting that $L$. vannamei can utilize dietary energy with the same efficiency from these sources, contrary to observations made with diets produced using CNA.

\section{Discussion}

Among dietary ingredients, soy bean meal is one of the most stu-

\begin{tabular}{|l|l|l|l|l|}
\hline Diets & ref. diet & SBM & FPM & \multicolumn{1}{l|}{$C N A$} \\
\hline $\mathrm{ADC}_{\mathrm{DM}}$ & $86.2 \pm 2.5 \mathrm{a}$ & $85 \pm 1.2 \mathrm{ab}$ & $86 \pm 1.5 \mathrm{a}$ & $80 \pm 2.3 \mathrm{c}$ \\
\hline $\mathrm{ADC}_{\text {protein }}$ & $95.5 \pm 0.9^{\mathrm{a}}$ & $95.8 \pm 0.7^{\mathrm{a}}$ & $95.8 \pm 0.5 \mathrm{a}$ & $94.2 \pm 1.0 \mathrm{~b}$ \\
\hline $\mathrm{ADC}_{\text {energy }}$ & $92.4 \pm 1.7 \mathrm{a}$ & $91.4 \pm 1.0 \mathrm{a}$ & $92.8 \pm 0.7 \mathrm{a}$ & $87.5 \pm 1.8 \mathrm{~b}$ \\
\hline
\end{tabular}

Values are means of four replicates \pm S.D. Means within columns with the same letter are not significantly different at $\mathrm{P}<0.05$

Table 3: Shrimp diet's ADC ( \pm S.D.) for dry matter, protein and energy.

\begin{tabular}{|c|c|c|c|}
\hline Ingredient & SBM & FPM & CNA \\
\hline $\mathrm{ADC}_{\mathrm{DM}}$ & $80.0 \llbracket \square 3.8 a$ & $87.0 \square \pm \square .0 \mathrm{a}$ & $64.0 \llbracket \pm 8.2 b$ \\
\hline$A D C_{\text {protein }}$ & $96.7 \llbracket \llbracket 2.7 a$ & $97.9 \llbracket \pm[3.7 a$ & $89.4 \llbracket \llbracket 4.8 \mathrm{~b}$ \\
\hline$A D C_{\text {energy }}$ & $88.9 \llbracket \square 3.4 a$ & $93.9 \llbracket \pm[2.6 a$ & $75.5 \pm \llbracket 6.4 b$ \\
\hline
\end{tabular}

Values are means of four replicates \pm S.D. Means within columns with the same letter are not significantly different at $\mathrm{P}<0.05$.

Table 4: Ingredient ADC ( \pm S.D.) for dry matter, protein and energy.

\begin{tabular}{|c|c|c|c|c|c|c|c|}
\hline & $\mathrm{DE}^{(1)}$ & $\mathrm{UE}+\mathrm{ZE} \mathrm{E}^{(2)}$ & $\mathrm{HiE}^{(3)}$ & $\mathrm{HeE}^{(4)}$ & $R E^{(5)}$ & $\begin{array}{l}\mathrm{HiE} \mathrm{mg} \mathrm{O} \\
\mathrm{g}^{-1} \mathrm{~h}^{-1}\end{array}$ & $\begin{array}{l}\mathrm{HeE} \mathrm{mg} \mathrm{O}_{2} \\
\mathrm{~g}^{-1} \mathrm{~h}^{-1}\end{array}$ \\
\hline SBM & 1.6 & 0.13 & 0.3 & 0.25 & 0.9 & 1.62 & 0.15 \\
\hline FPM & 1.4 & 0.11 & 0.3 & 0.32 & 0.7 & 1.27 & 0.20 \\
\hline CNA & 1.0 & 0.06 & 0.3 & 0.30 & 0.4 & 1.47 & 0.18 \\
\hline
\end{tabular}

(1)DE: digestible energy values from ADC experiment.

(2) $U E+Z E$ : urinary and gill excretion (Bureau et al., 2000).

(3) $\mathrm{HiE}$ : heat increment of feeding on the basis of one meal per day.

${ }^{(4)} \mathrm{HeE}$ : maintenance based on value measured at $\mathrm{t}_{0}$.

${ }^{(5)} \mathrm{RE}$ : recovered energy.

Table 5: Impact of feed composition on energy budget $\left(\mathrm{kJ}\right.$ shrimp $\left.{ }^{-1} \mathrm{day}^{-1}\right)$ for individual animals placed in a metabolic chamber for $24 \mathrm{~h}$. 
died in the context of shrimp nutrition and feeding [7,18,36,37]. To determine suitability of alternate dietary ingredients, particularly from vegetable sources such as pea meal, sorghum and canola meal, the determination of nutrient digestibility is important priority. Nutrient digestibility controls energy partitioning by the animal; furthermore, protein is important for growth and energy [38]. In the present study, $\mathrm{ADC}_{\mathrm{DM}}$ with de-hulled, micro-ground, extruded P. sativum meal $(\mathrm{FPM})$ reached $87 \%(\mathrm{p}<0.05)$ and indicated the level of carbohydrate digestion.

FPM-fed tiger shrimp showed an $80 \%$ ADCDM that is comparable to values reported by Smith et al. [36] and in P. monodon [9]. With 73\% $\mathrm{ADC}_{\mathrm{DM}}$ for SBM at two substitution levels, L. vannamei displayed values that varied from $61-85 \%$ [7]. These measurements contrasted with the values generally obtained at $30 \%$ inclusion; CNA yielded the lowest value, $64 \%(\mathrm{p}<0.05) . \mathrm{ADC}_{\text {energ }}$ in this trial reached $88.9 \%$ with $\mathrm{SBM}$ at an inclusion level of $30 \%$. Thus, SBM values were within the range previously observed for L. vannamei (79-100\%), even though shrimp were fed at two levels of fishmeal substitution [7]. At this level of inclusion, protein digestibility of ingredients was found to be high, around $90 \%$ in all trials. ADC ${ }_{\text {protein }}$ of an ingredient or feed provides a practical value that sometimes could be considered as overestimated from the viewpoint of nutrient availability [15]. P. stylirostris extruded feces that leached an amount of protein and carbohydrates estimated at 4 and $8 \%$, respectively after $6 \mathrm{~h}$ immersion [39]. However, high $\mathrm{ADC}_{\text {protein }}$ values in the present study were in accordance with those reported for SBM $[18,19]$. The effect of protein level on ADC needs to be investigated further for possible associative effects as described for quality protein sources such as SBM. SBM has been the focus of studies due to its digestibility [18] and amino acid profile in shrimp muscle; these factors make it an ideal candidate for feed formulation. High ADC ${ }_{\text {protin }}$ values observed for CNA [13] and FPM [36] were similar to those observed here, with values falling between $91-94 \%$.

In the evaluation of diets including an ingredient supplemented at levels of $30 \%$, feed intake is a first concern. However, the formulation in the present study did not produce any real effect on ingestion, and the experimental diets formulated with plant-based ingredients showed no decrease in digestibility as compared to the reference diet, indicating that the vegetable components replacing fish meal in this study did not affect the digestive process of shrimp, as has been found in previous studies [37]. Energy content differed between SBMd and FPMd as compared to CNAd; this may be due to the higher fiber level in CNAd, unidentified anti-nutritional factors, or the way ingredients were prepared. It is interesting to note that the ADC level differed significantly from one plant source to another; it will be important to determine the reasons for these variations. The main factors influencing the digestibility of proteins may be related to factors linked to the protein itself, including its quaternary or tertiary structure and the possible aggregation of $\mathrm{H}$-linked sub-units as occurs in the case of keratin, with disulfide bridges that may affect protein solubility. A secondary structure with disulfide linkages could also have an effect, especially in the case of keratin. There is documented impact of heat denaturing on animal proteins such as blood meals; this phenomenon may be expected to have only moderate impact on plant proteins fed to rats [40]. Plant proteins such as SBM are less readily hydrolyzed as compared to their native form, which is more compact than the denatured protein. Finally the primary structure may have an effect due to the distribution of peptide linkages near the $\mathrm{NH}_{3}$ or $\mathrm{COOH}$ terminal and to the frequency of amino acids such as diacids, or alternately to the frequency of basic amino acids (Lys and Arg), which are targets for proteases. Among extrinsic factors, we noted the presence of inhibitors such as anti-trypsins or tannins and phytic acid. Anti-nutritional factors were substantially reduced in plant concentrates or eliminated from meals by adequate selection programs [41]. In the case of concentrates, an apparent benefit for plant digestibility could be linked with technological improvement during processing (Maldonado pers.com.). The accessibility of proteins to enzymes will depend on cellulose membranes and the fineness of particles. There are other factors modifying transit such as raw starch, lipids or pharmacodynamic action. In addition to factor acting on digestion, other factors may modify absorption, such as the equilibrium between amino acids and the competition for transport systems, although these are likely to be of minor importance [42]. Some researchers have hypothesized the existence of a relationship between biological value $(\mathrm{BV}=$ proteic accretion/absorbed protein) and digestibility, but in practice, this is not found because BV is not additive. In summary, the digestibility of proteins will depend on many physical and nutritional factors that can vary in intensity from one ingredient to another as displayed in Table 6.

Diets evaluated for digestibility were used to establish an energy budget and trace the energy derived from both protein and energy fractions (carbohydrate and lipid) in each diet. The estimated value of excretion with CNAd was only about $0.06 \mathrm{~kJ} \mathrm{shrimp}^{-1} \mathrm{day}^{-1}$. Heat increment (HiE) values and maintenance (HeE) with SBMd, FPMd and CNAd were similar. HeE did not change in the range of dietary protein levels selected for this experiment but HiE in juvenile L. stylirostris changed regardless of whether marine protein $(0.14 \mathrm{~kJ})$ or plant sources $(0.3 \mathrm{~kJ})$ were used [27]. Plant protein produced higher energy expenditure in P. japonicus [43]. This population did not respond similarly when fed soy protein concentrate; heat production as percentage of gross energy was high when compared to shrimp ingesting marine protein sources. Shrimp use energy for activity; this is one of the most difficult parameters to control in this type of study. When comparing two concentrates such as crab and soya, it could be expected that HiE should be reduced in crab, which is theoretically a better protein source. Among other bioenergetic parameters affecting the energy budget, recovered energy (RE) differed between treatments. In general, RE remained higher for shrimp receiving animal protein than for shrimp ingesting plant protein, as shown in P. japonicus with 20 and $9 \%$ for crab protein and soy protein, respectively [43]. These findings are in line with results from P. stylirostris [27] and L. vannamei (in the present study). RE gives an estimate of the energy channeled to weight gain, and while no data on growth are presented here, the trend indicates an equal potential for growth for each of the four diets. Ratios reported for reported digestible protein (DP) show an average DP/DE equal to $23 \mathrm{mg} \mathrm{k}^{-1}$ (22-25), coinciding with previous data [44]. Values above or below this would produce weight gain under optimum laboratory conditions with animals raised in clear seawater. Energy budgets have been reported $[45,46]$ for penaeid larvae. These energy budgets can be limited in the presence of low reserves, which in turn necessitate frequent feeding that is rare among juveniles. Notably, reserves (lipid and glycogen) were not taken into account in the course of respirometry trials, contrasting with the approach of dynamic energy budget (DEB) analysis. According to this methodology, data are used to create a dynamic repartition of energy for growth or reproduction and to engineer a predictive model [47].

\begin{tabular}{|l|l|l|l|}
\hline fineness $(\mu)$ & 800 & 250 & 80 \\
\hline water capacity $(\%)$ & +++ & $50-400$ & ++ \\
\hline cellulose $(\%)$ & 3.4 & 1.4 & 13 \\
\hline tannins & & & ++ \\
\hline trypsin inhibitor $(\mathrm{mg} / \mathrm{g})$ & $<4$ & & \\
\hline trypsin inhibitor $(\mathrm{UI})$ & & 600 & \\
\hline accessibility to proteases & +++ & +++ & ++ \\
\hline
\end{tabular}

Table 6: Impact of physical and biological factors on ADC of ingredients. 
Currently, SBM is one of the main alternatives to the use of fishmeal in shrimp diets, along with meals from sources such as lupin, sorghum, pea, canola, cotton and sunflower. In addition, there are a number of potential protein concentrates that may also be used including soya, wheat, and potato. Thus, there are additional options available for achieving feed formulations without fishmeal that have no negative impact on shrimp texture, nutrition or flavor.

\section{Acknowledgments}

Financial support for this study was provided by Corporación Centro Investigación de la Acuicultura de Colombia CENIACUA and ALICORP (Perú) and technica assistance was provided by Unidad Multidisciplinaría de docencia e Investigación UNAM. Sincere thanks to Brenda Montavan (Alicorp Perú) for her support and collaboration. The authors appreciate the constructive input from Dagoberto Sanchez (Alicorp Perú), Carlos Rosas, Javier Chiappa, Carlos Maldonado (UNAM, México), David Griffith (Cartagenera de Acuacultura) and Roberto Mercado, Julia Verde Star (Universidad Autónoma de Nuevo León, México).

\section{References}

1. FAO (2008) The State of World Fisheries and Aquaculture. FAO, Rome, Italy $18-48$.

2. Samocha TM, Davis AD, Soud PI, DeBault K (2004) Substitution of fishmeal by co-extruded soybean poultry by-product meal in practical diets for the Pacific white shrimp, Litopenaeus vannamei. Aquaculture 231: 197-203.

3. Tacon AGJ, Akiyama DM (1997) Feed ingredients. In: D'Abramo LR, Conklin DE, Akiyama DM (Eds.), Crustacean Nutrition. Advances in World Aquaculture vol 6 World Aqua Soc Baton Rouge, LA, USA 411-472.

4. AOAC $(1990,2000,2004)$ Official Methods of Analysis of AOAC International. 12th ed. 17th ed. Association of Official Analytical Chemist, Washington, DC, USA.

5. King D (2004) Implications of the replacement of fishmeal in diets for tropica aquaculture species on nutrition and feed formulation. Master Literature Review.

6. Amaya E, Davis A, Rouse D (2006) Replacement of fishmeal in practical diets for the pacific white shrimp (Litopenaeus vannamei) reared under pond conditions. Aquaculture 262: 291-298.

7. Divakaran S, Velasco M, Beber E, Forster I, Tacon A (2000) Soybean meal apparent digestibility for Litopenaeus vannamei. Avances en Nutrición Acuícola V. Memorias del V Simposium Internacional de Nutrición Acuícola. Noviembre 19-22. Mérida, Yucatán, México.

8. Piedad-Pascual F, Cruz EM, Sumalangcay A Jr (1990) Supplemental feeding of Penaeus monodon juveniles with diets containing various levels of defatted soybean meal. Aquaculture 89: 183-191.

9. Bautista-Teruel M, Eusebio P, Welsh T (2003) Utilization of feed pea, Pisum sativum, meal as a protein source in practical diets for juvenile tiger shrimp, Penaeus monodon. Aquaculture 225: 121-131.

10. Davis DA, Arnold CR, Mc Callum I (2002) Nutritional value of feed peas (Pisum sativum) in practical diet formulations for Litopenaeus vannamei. Aquaculture Nutrition 8 : 87-94.

11. Bell JM (1993) Factors affecting the nutritional value of canola meal: a review. Can J Anim Sci 73: 689-697.

12. Buchanan J, Sarac HZ, Poppi D, Cowan RT (1997) Effects of enzyme addition to canola meal in prawn diets. Aquaculture 151: $29-35$.

13. Cruz-Suarez LE, Ricque-Marie D, Tapia-Salazar M, McCallum IM, Hickling D (2001) Assessment of differently processed feed pea (Pisum sativum) meals and canola meal (Brassica sp.) in diets for blue shrimp (Litopenaeus stylirostris). Aquaculture 196: 87-104.

14. Goldblatt MJ, Conklin DE, Brown WD (1980) Nutrient leaching from coated crustacean rations. Aquaculture 19: 383-388.

15. Smith DM, Tabrett SJ (2004) Accurate measurement of in vivo digestibility of shrimp feeds. Aquaculture 232: 563-580.

16. Sales J, Britz JP (2002) Evaluation of the reference diet substitution method for determination of apparent nutrient digestibility coefficients of feed ingredients for South African abalone (Haliotis midae L.). Aquaculture 207: 113-123.
17. Lee PG, Lawrence AL (1997) Digestibility. In: D'Abramo, L.R., Conklin D.E.,Akiyama, D.M. (Eds.), Crustacean Nutrition, Advances in World Aquaculture, vol. 6. World Aqua. Soc., Baton Rouge, LA, USA, 194-260.

18. Akiyama D, Coelho M, Lawrence AL, Roberson EH (1989) Apparent digestibility of feedtuffs by the marine shrimp Penaeus vannamei Boone. Nippon Suisan Gakk 55: 91-98.

19. Brunson JF, Romaire RP, Reigh RC (1997) Apparent digestibility of selected 361 ingredients in diets for white shrimp Penaeus setiferus L. Aquaculture Nutrition 3: 9-16.

20. Forster I (1999) A note on the method of calculating digestibility coefficients of nutrients provided by single ingredients to feeds of aquatic animals. Aquaculture Nutrition 5: 143-145.

21. Lemos D, Navarete del Toro A, Cordova-Murueta JH, Garcia-Carreno F (2004) Testing feeds and feed ingredients for juvenile pink shrimp F.paulensis: in vitro determination of protein digestibility and proteinase inhibition. Aquaculture 239 307-321.

22. Cousin M, Cuzon G, Guillaume J (1996) Digestibility of starch in P.vannamei: in vivo and in vitro study on 8 samples of various origins. Aquaculture 140 361-372.

23. De la Noüe J, Choubert G, Pagniez B, Blanc JM, Luquet P (1980) Mesure des coefficients d'utilisation digestive chez la truite arc-en-ciel. Etude des temps d'adaptation à un nouveau régime, du temps de récolte des feces et du nombres des répétitions. Canadian J Fish Aquat Sci 37 : 2218-2224.

24. Cho CY, Bureau DP (1998) Development of bioenergetic models 381 and the Fish-PrFEQ software to estimate production, feeding ration and waste output in aquaculture. Aquat Living Resour 11: 199-210.

25. Cui Y, Xie (1999) Modelling growth in fish. In Feeding Systems and Feed evaluation Models. MK Theodorou, and J France, edn. CAB International, Wallingford, UK. pp 413-434.

26. Bureau DP, Kaushik SJ, Cho CY (2002) Bioenergetics. In Fish Nutrition. JE Halver and RW Hardy, edn. Academic Press, San Diego, California, pp 1-53.

27. Gauquelin F, Cuzon G, Gaxiola G, Rosas C, Bureau D, et al. (2007) Effect of dietary protein level on growth and energy utilization by Litopenaeus stylirostris under laboratory conditions. Aquaculture 271: 439-448.

28. AOAC (2000) Official Methods of Analysis of AOAC International, 17th edn. Association of Official Analytical Chemists, Gaithersberg, USA.

29. Aquacop (1978) Study on nutritional requirements and growth of Penaeus merguiensis in tanks by means of purified and artificial diets. Proceed World Mar Soc Ann Meeting 9: 225-234.

30. Atkinson JL, Hilton JW, Slinger SJ (1984) Evaluation of acid-insoluble ash as an indicator of feed digestibility in rainbow trout (Salmo gairdneri). Can J Fish Aquat Sci 41: 1384-1386.

31. NRC (1981) Nutrient Requirements of Fish. National Research Council, Washington, DC: National Academy Press.

32. Rosas C, Martínez E, Gaxiola G, Díaz E, Brito R, et al. (1998) Effect of dissolved oxygen on the energy balance and survival of Penaeus setiferus juveniles. Mar Ecol Prog Ser 174: 67-75.

33. Bureau DP, Azevedo PA, Tapia-Salazar M, Cuzon G (2000) Pattern and cost of growth and nutrient deposition in fish and shrimp: potential implications and applications. In: Cruz-Suárez E, Ricque-Marie D, Tapia-Salazar M, CiveraCerecedo R (Edn). Avances en Nutrición Acuícola V. Memorias del V Simposio Internacional de Nutrición Acuícola, Mérida Yucatán, México, pp 111-140.

34. SAS $®$ 9.1.3 Copyright (2002-2005) SAS Institute Inc. Neuenheimer Landstr.28-30. Heidelberg, Germany.

35. Cuzon G, Guillaume J (2001) Nutrition and feeding of shrimps in intensive and extensive culture. Nutrition and feeding of fish and crustaceans. Guillaume J, Kaushik S, Bergot P, Metailler R (edn), 265-277.

36. Smith DM, Tabrett SJ, Sarac, HZ (1999) Fish meal replacement in the diet of the prawn Penaeus monodon. Book of abstracts of the World Aqua. Soc. Ann. Meeting '99, Sydney, Australia. WAS, Baton Rouge, LA, USA, 707. 
Citation: Suárez JA, Gaxiola G, Posso R, Garcia G, Alanis G, et al. (2012) Energy Partitioning by Litopenaeus Vannamei (Boone, 1931) Given Plant Protein Diets. J Aquac Res Development 3:128 doi:10.4172/2155-9546.1000128

37. Suarez JA, Gaxiola G, Mendoza R, Cadavid S, Garcia G, et al. (2009) The substitution of fishmeal with plant protein sources and energy budget for white shrimp L.vannamei (Boone, 1931). Aquaculture 289: 118-123.

38. Cho CY, Kaushik SJ (1990) Nutritional energetics in fish: energy and protein utilization in RT (Salmo gairdneri). World Rev Nut diet 61: 132-172.

39. Fenucci JL, Fenucci AC, Lawrence LA, Zein Eldin Z (1982) The assimilation of protein and carbohydrate from prepared diets by the shrimp L.stylirostris. Journal of the World Mariculture Society $13: 134-135$

40. Fukushima $D(1968)$ Internal structure of $7 S$ and 11 g globulin molecules 432 in soyabean proteins. Cereal Chem 45: 203-206.

41. Castell AG, Guenter W, Igbasan FA (1996) Nutritive values of peas for nonruminant diets. Anim Feed Sci Technol 60: 209-227.

42. Lee JAC, James PS, Smith MW, Cossins AR (1991) Amino acid transport in the intestinal mucosa of temperature-acclimated carp. J Thermal Biol 16: 7-11.
43. Koshio S, Teshima SI, Kanazawa A, Takahiro Watase (1993) The effect of dietary protein content on growth, digestion efficiency and nitrogen excretion of juveniles kuruma prawn, P.japonicus. Aquaculture 113: 101-114.

44. Cousin M (1995) Contribution à l'étude de l'utilisation des glucides et du rapport proteine/énergie chez P.vannamei et P.stylirostris. PhD. thèsis, Paris, pp 201.

45. Kurmaly K, Yule AB, Jones DA (1989) An energy budget for the larvae of Penaeus monodon (Fabricius). Aquaculture 81: 13-25.

46. Divakaran S, Forster IL, Velasco M (2004) Limitations on the use of shrimp L.vannamei midgut gland extract for the measurement of in vitro protein digestibility. Aquaculture 239: 323-339.

47. Koojiman SALM (2000) Dynamic energy budget in biological systems and mass budget. Cambridge University Press, Cambridge, 424. 